\title{
Historical Review of Control Programs for Levuana iridescens (Lepidoptera: Zygaenidae) in Fiji and Examination of Possible Extinction of This Moth by Bessa remota (Diptera: Tachinidae) ${ }^{1}$
}

\author{
Mark S. Hoddle ${ }^{2}$
}

\begin{abstract}
Coconut production in Fiji was a mainstay of the economy and indigenous culture in the late 1800s to early 1900s. From around 1877 coconut production on Viti Levu was severely affected by Levuana iridescens BetheuneBaker, a small purple moth, whose larvae trenched the underside of coconut leaves. A variety of cultural and chemical control strategies over approximately a 16-yr period failed to bring this pest under effective control. A biological control program initiated in 1925 resulted in importation and release of a parasitic fly, Bessa remota (Aldrich), which provided immediate and effective control of $L$. iridescens. This well-documented classical biological control program has subsequently become highly controversial with regard to arguments over endemicism of $L$. iridescens to the Fijian archipelago and the possibility that $B$. remota has caused the extirpation of $L$. iridescens and the endemic Heteropan dolens Druce in Fiji. A synopsis is provided of the cultural, chemical, and biological control programs for L. iridescens in Fiji. In addition, evidence for extinction of $L$. iridescens and $H$. dolens is examined through an analysis of little-known literature and neglected museum records. It is suggested that the reason for lack of reports of L. iridescens after 1956 was due to the declining value of copra, which resulted in less research on coconuts; the recall from Fiji of entomologists that worked on the L. iridescens control program by the Imperial Bureau of Entomology; and the subsequent increased abundance of another leaf-trenching lepidopteran, Agonoxena argaula Meyrick, which would have made easy detection of low-density L. iridescens populations difficult. To verify the continued presence of $L$. iridescens and $H$. dolens in Fiji will require a comprehensive campaign employing visual searches of coconut palm fronds, the use of ground and aerial malaise traps, canopy fogging, and perhaps chemical analysis of unidentified lepidopteran pupal cocoons found on the thatch of coconut fronds for comparison with chemical profiles of known L. iridescens cocoons.
\end{abstract}

LEVUANA IRIDESCENS Bethune-BAKER (Figure $1 A$ ) is known only from Fiji, an archipelago of approximately 300 islands in the South Pacific. Levuana is a monotypic zygaenid genus containing one described species, iridescens Bethune-Baker, 1906. Levuana iri-

\footnotetext{
${ }^{1}$ Manuscript accepted 25 January 2006.

2 Department of Entomology, University of California, Riverside, California 92521 (phone: 909-787-4714; fax: 951-827-3086; e-mail: mark.hoddle@ucr.edu).
}

Pacific Science (2006), vol. 60, no. 4:439-453

(C) 2006 by University of Hawai'i Press

All rights reserved descens is a purple moth that was first recorded as a serious coconut pest around 1877 from a single island, Viti Levu, in Fiji. Earlier records on coconut production from 1846 and 1860 do not indicate any severe and widespread maladies affecting palms, especially those caused by obvious and attractive Lepidoptera (Simmonds 1924). On Viti Levu, after 1877 , outbreaks of L. iridescens were frequent and devastated coconut palms because feeding moth larvae trenched the underside of leaves, which promoted defoliation and subsequent palm mortality. As a consequence, copra (i.e., dried coconut meat from which coconut oil is extracted) production was severely affected and coconut cultivation be- 


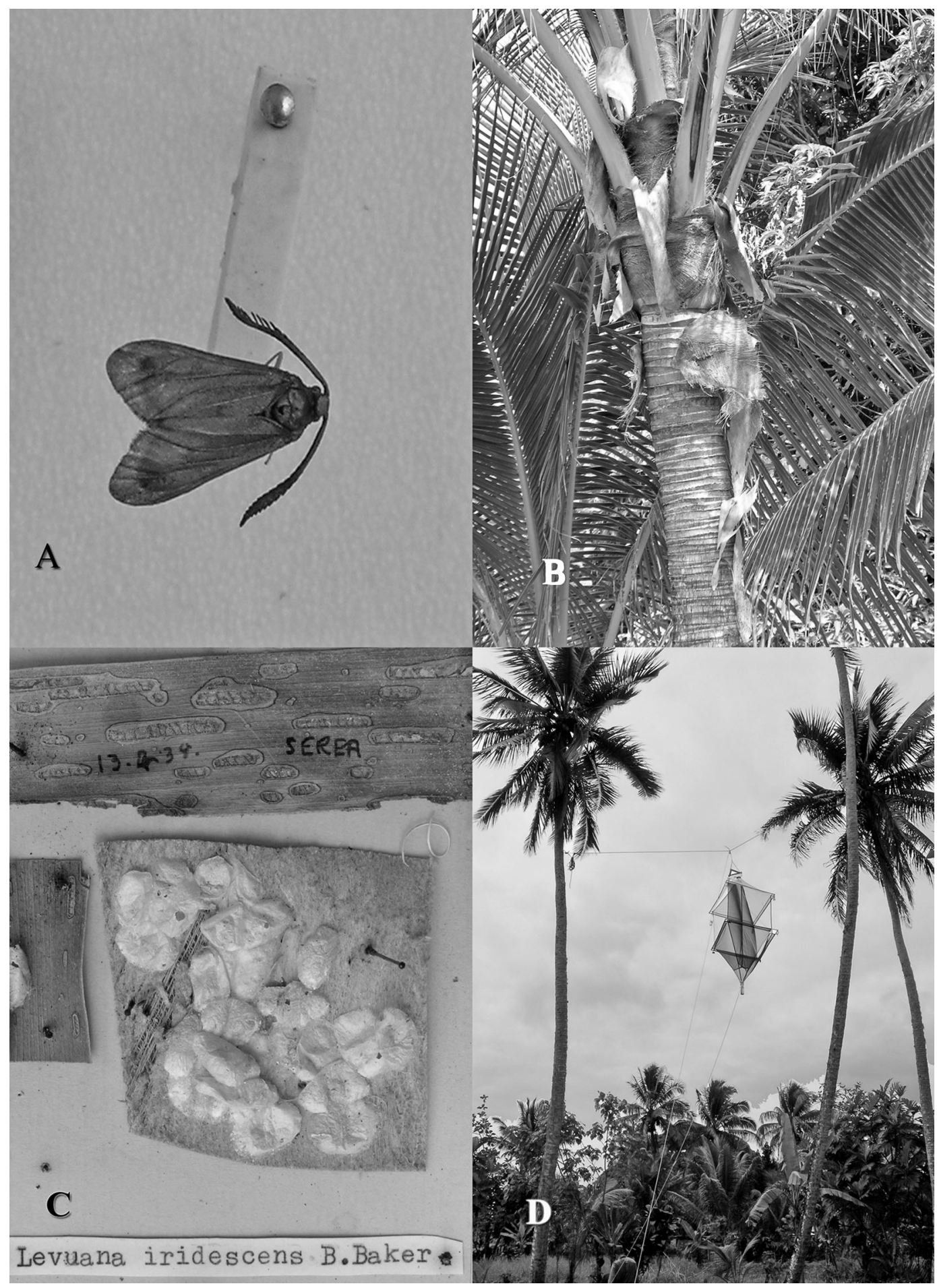

Figure 1. A, An unlabeled specimen of Levuana iridescens from the Koronivia Research Station that is now in the Entomology Museum, University of California, Riverside. $B$, Base of a coconut palm crown showing vulu, the brown thatchlike material that was the favored site for pupation by L. iridescens larvae. C, Pupal cocoons of L. iridescens on vulu and a coconut leaf showing feeding damage by L. iridescens larvae; writing on damaged leaf is Serea 13 April 1939. D, Aerial malaise trap deployed at Serea on Viti Levu, Fiji, October 2004. 
came unprofitable on Viti Levu. Indigenous Fijian culture, which relied on the coconut for food, water, fiber, medicinal products, fuel, and building materials, was threatened as a result of this coconut pest (Tothill et al. 1930).

Since its first detection around 1877, L. iridescens was restricted to Viti Levu for approximately $40 \mathrm{yr}$ before it began expanding its range in 1916 to close offshore islands where conditions favored pest establishment and proliferation (Figure 2). The highly restricted geographic range of L. iridescens was considered a "fact contrary to the usual position with regard to the endemic fauna of Fiji" (Simmonds 1924:2). Scientists devising management schemes for L. iridescens concluded that the pest was not endemic to Fiji, even though it was known only from Viti Levu, and was most likely an exotic invader from elsewhere in the Pacific (Simmonds 1921a, 1924).

This conclusion was arrived at because $L$. iridescens exhibited frequent and persistent outbreaks that regularly killed its host plants, the moth was expanding its geographic range, and $L$. iridescens lacked specialized parasitoids associated with eggs, larvae, and pupae. These facts were recognized as very peculiar aspects of this pest's ecology, especially when compared with other zygaenid species, which in their native range outbreak infrequently, persist at extremely low population densities, do not exhibit range expansion, and have diverse suites of associated natural enemies that effectively regulate population growth (Simmonds 1924, 1930a, Tothill et al. 1930). This circumstantial evidence did not, however, prove conclusively that L. iridescens was a species exotic to Fiji but did strongly suggest that the moth had originated elsewhere and immigrated to the Islands (Tothill et al. 1930). Unless L. iridescens is found outside Fiji the tautology of this endemicity argument is difficult to resolve conclusively.

Research on control methods for L. iridescens falls into two categories: (1) attempts at cultural and chemical control over a $\sim 16-\mathrm{yr}$ period (1909-1925), and (2) initiation of a biological control program that began in 1925 and permanently solved the L. iridescens problem in Fiji. The biological control program for L. iridescens is well known and documented (Tothill et al. 1930). However, the pre-1925 attempts at developing management programs for L. iridescens are not well known due to project reports and articles being recorded in little-known and difficult-to-locate periodicals. The remainder of this article summarizes the many efforts at cultural and chemical control, provides an overview of the biological control program, addresses the controversial issue of the extinction of $L$. iridescens and Heteropan dolens Druce (Lepidoptera: Zygaenidae), and finally provides suggestions on how the continued presence of L. iridescens in Fiji may be verified.

THE PRE-1925 MANAGEMENT STRATEGIES FOR LEVUANA IRIDESCENS IN FIJI

\section{Host Plant Resistance}

Oviri coconuts from Tahiti were tested for resistance to feeding by L. iridescens larvae. The astringent properties of this coconut variety were presumed to act as potential deterrents to herbivory, and lack of obvious insect attack on coconuts in Tahiti provided anecdotal field evidence suggesting that Oviri coconuts may be unpalatable to phytophagous insects (Simmonds 1920). Importation of Oviri coconuts into Fiji and subsequent feeding trials assessing palatability to emergent and half-grown L. iridescens larvae were inconclusive, leading to the decision that high-yielding resistant coconut varieties were not likely to be found easily (Simmonds 1921a).

\section{Plantation Management}

To reduce the debilitating impact of $L$. iridescens outbreaks on palm growth, practices designed to promote plant vigor were promoted to enable infested palms to grow through defoliation events. Outreach programs encouraged plantation managers to control weeds, thin overcrowded plantations, use soil amendments, and drain swampy ground (Tothill 1926). There are no data indicating the success of these suggested practices or the extent to which they were employed for L. iridescens control. 


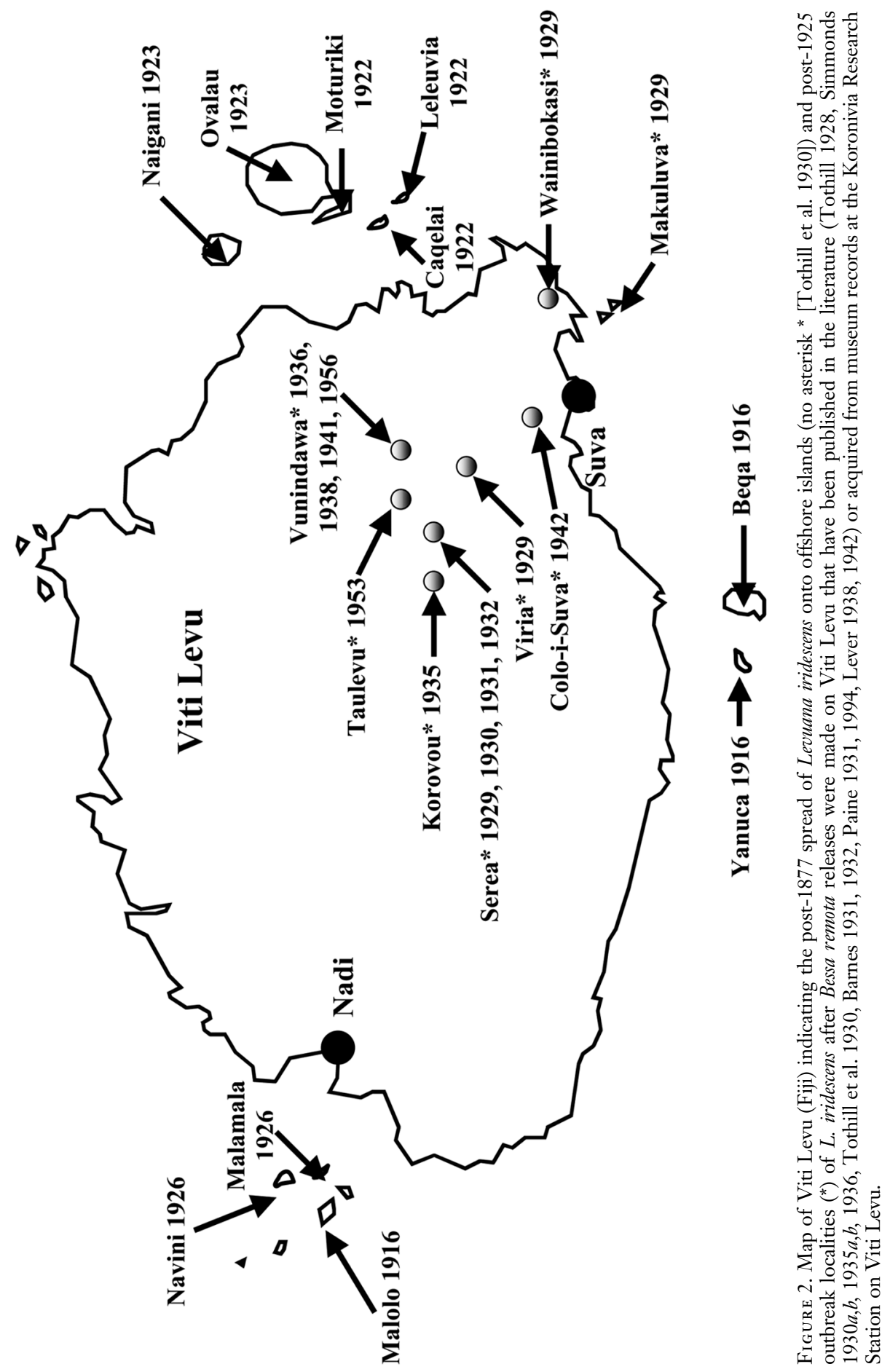


Traps

Light traps set at night were assessed for their ability to attract adult $L$. iridescens. This moth is a day-flying insect, so powerful acetylene lamps set over pans of kerosene mixed with water failed to attract moths at night (Knowles 1919). Adult moths had been observed feeding at a variety of different flowers including Lantana camara, coconut, mango (Mangifera indica), ginger (Zingiber spp.), mile-a-minute (Polygonum perfoliatum), and Tournefortia argentea (Simmonds 1925, Tothill et al. 1930). Oddly, phenol and tar also had alluring properties (Simmonds 1925). Knowles (1919) speculated that if attractive volatile additives could be identified and isolated they could be used to increase the attractiveness of traps to adult moths, thereby enhancing the utility of this method of control. There is no published research assessing the feasibility of using traps for monitoring L. iridescens populations, determining pest phenology, or implementation for localized control efforts.

\section{Vulu Stripping}

Vulu is the thatch or fiber matting that connects the bases of coconut fronds (Figure 1B). Levuana iridescens larvae preferentially pupate in vulu (Figure $1 C$ ). During Levuana outbreaks, densities of pupating larvae in vulu could become so great that cocoons were spun over the top of existing cocoons, making emergence impossible for larvae in lower strata (Tothill et al. 1930). Manual removal of vulu as a pest suppression tactic was considered but quickly abandoned due to the intensive amount of labor required and the difficulty of quickly ascending and descending tall coconut palms. In addition, vulu removal destroyed habitat used by beneficial arthropods such as spiders that preyed upon pests (Knowles 1909).

\section{Host Plant Eradication}

In addition to coconut, $L$. iridescens larvae feed on several other palm species, including Ptychosperma (=Actinophloeus) macartburi,
Areca catechu (betel nut), Elaeis guineensis, Bactris gasipaes (=Guilelma speciosa), Livistonia chinensis and L. speciosa, Roystonea (=Oreodoxa) regia, $R$. (=Oreodoxa) oleracea (royal palm), Sabal palmetto, Sagus vitiensis (native sago palm), and Veitchia joannis (niu sawa). During severe outbreaks, high densities of $L$. iridescens would "spill over" onto less-preferred hosts, and eggs and feeding larvae would be found on Artocarpus incisa (breadfruit), bananas, reeds, sugarcane, and unidentified orchids (Simmonds 1925, Tothill et al. 1930). "Drastic steps" such as the removal of food sources "to starve out" L. iridescens were considered necessary in combination with burning and arsenical sprays to eradicate $L$. iridescens on recently invaded islands that lay offshore from Viti Levu (Simmonds 1922). A similar project proposed for Viti Levu would have eradicated all preferred hosts, in particular coconuts and royal palms. The enormity of the project, the cost, and the uncertainty of eliminating every host plant led to the abandonment of this strategy at an early stage of planning (Simmonds 1922, 1924).

\section{Quarantine Inspections to Prevent Unintentional Spread}

In 1924, seaports at Suva, Levuka (all coconuts within 0.5 miles $[\sim 800 \mathrm{~m}]$ of this wharf were destroyed), and Lautoka were designated as inspection ports under the Diseases of Plants Ordinance (1913), and interisland cutters were required to stop for inspection before moving from infested zones to noninfested zones (Tothill et al. 1930). A tripartite cooperative involving growers, The Native Department, and the government oversaw the inspection process. Vessels without special exemptions (some passenger, plantationowned, and freight boats were not legally required to stop) were subjected to inspection at one of the three ports and were awarded an Inspection Certificate and entry records were gazetted. Vessel inspections were voluntarily overseen by growers who had the authority to destroy all "objectionable and dangerous material" on boats moving between islands (Tothill 1925a). Objectionable and dangerous material of primary concern 
was the movement of vulu between islands. Vulu was regularly harvested and used as packing material, for wrapping perishable (e.g., taro roots and medicines) and fragile items, and enclosing letters (Tothill 1925a). Vulu is the preferred pupation site for L. iridescens larvae, and pupae on vulu can survive without sustenance for up to 9 days, making human-mediated long-distance transport of this life stage plausible (Tothill 1925a). The inspection system remained in place until 1928, "by which time Levuana moth had been reduced to a condition of impotency" by Bessa remota (Aldrich) (see later in this article) (Tothill et al. 1930:84).

\section{Chemical Control}

The need to quickly control outbreaks of $L$. iridescens and for eradication of incipient populations of this pest as it expanded its range to islands surrounding Viti Levu prompted investigation of insecticides as a control strategy. Efficacy of stomach poisons applied as foliar sprays mixed with seawater were assessed over the period 1909-1925. Insecticides were evaluated with seawater as the carrier because seawater is more readily available than freshwater in Fiji (Knowles 1909) and coconuts have a high tolerance to being drenched with seawater (Tothill et al. 1930). One pound $[0.45 \mathrm{~kg}]$ of arsenic boiled with soda and mixed with 400 gallons [1,514 liters] of seawater, starch (as a sticker), and whiting (for coloration) readily killed L. iridescens larvae (Knowles 1919). Alternatively, 1.5 lbs [0.68 kg] of either lead or calcium arsenate mixed with 40 gallons [151 liters] of seawater killed larvae within 5-10 days and provided control for up to 2 months (Tothill 1925b). Approximately 12-24 months of suppression was achieved with $2.5 \mathrm{lbs}$ [1.13 kg] of dry lead arsenate mixed with 40 imperial gallons [182 liters] of seawater when applied to the underside of coconut leaves. Paris green was unsuitable because of phytotoxicity and poor adhesion to coconut leaves (Tothill et al. 1930).

Application of sprays to tall palms involved either the use of a power-driven pump or the erection of scaffolding around each palm to be treated by hand. A major shortcoming associated with power application of wet sprays to tall coconut palms was the enormity of wasted spray to provide adequate coverage of infested coconut crowns. Costs associated with the employment of spray crews (Knowles 1919) and scaffold erection and movement were prohibitively expensive for hand applications that treated palm crowns at close range (Knowles 1919). Small coconut palms were successfully hand-treated for $L$. iridescens with kerosene emulsions or resin washes (Froggatt 1914), and applications of 30 ounces $[850 \mathrm{~g}]$ of lead arsenate in 25 gallons [95 liters] of water applied at a rate of 4 gallons [15 liters] per palm with applications repeated at 5-week intervals also controlled larvae on small palms (Jepson 1915).

A spray rig designed for rapid deployment against incipient $L$. iridescens populations on previously uninfested islands was custommade for use in Fiji. This spray rig consisted of a seagoing barge with a motorized FitzHenry Guptill solid-stream sprayer attached to its deck. A galvanized iron structure was built to cover the pump to protect both it and the crew from adverse weather and excessive sun exposure. The barge was towed by a launch along coastlines, and spray hoses up to 0.5 miles $[0.8 \mathrm{~km}]$ long could be dragged into plantations needing treatment. The barge had ready access to seawater for mixing with poisons, and beach access overcame difficulties of getting spray equipment into areas that lacked roads (Tothill 1925c). Trees 60-80 feet $[18-24 \mathrm{~m}]$ tall could be treated when weather conditions were appropriate, and coconuts in close proximity to beaches and within drag-line distance could be treated with this spray rig. The rapid deployment capability of the floating spray rig was never tested because $B$. remota rendered obsolete the need for insecticidal controls and treatment of new infestations on previously uninfested islands (Tothill et al. 1930).

Fumigation of infested coconut plantations was also investigated. Sulfur mixed with tar was burned over dry coconut leaves. This resulted in a thick smoke that wafted through infested plantations. Unless L. iridescens larvae were actually scorched by the flames they suf- 
fered no mortality. Clouds of smoke in plantations were never dense enough to suffocate adult moths but did succeed in agitating adult moths, thereby encouraging flight and dispersal (Knowles 1919).

$$
\begin{gathered}
\text { THE "LEVUANA CAMPAIGN" AND } \\
\text { INITIATION OF A BIOLOGICAL CONTROL } \\
\text { PROGRAM }
\end{gathered}
$$

To curb the spread and impact of L. iridescens in Fiji and limit the threat to other coconutgrowing nations in the South Pacific the "Levuana Campaign" was initiated in 1925 after a $£ 5,000$ reward failed to conjure a solution to the problem. The leader of the campaign, J. D. Tothill, and his two associates, T. H. C. Taylor and R. W. Paine, were given a 2-year contract to resolve the problem. Tothill viewed biological control as the only feasible and sustainable option available for permanently suppressing $L$. iridescens.

Levuana iridescens was not considered native to Fiji, and its home range was presumed to lie to the northwest of Fiji (Tothill et al. 1930). The assumption for this geographic area of origin was that from 1802 onward a vigorous trade in sandalwood was routed from Cochin China (i.e., South Vietnam) through Fiji and the New Hebrides (i.e., Vanuatu) to areas east of Fiji. From 1864 onward, extensive recruitment of labor for Fijian plantations from the Solomons and Vanuatu occurred, and this was considered another possible area from which L. iridescens may have originated (Simmonds 1924).

\section{Foreign Exploration for Levuana iridescens}

Extensive foreign exploration by Simmonds (1924) for approximately 9 months (14 June 1922-11 February 1924) of coconut palms and native palms such as sago was conducted throughout New Guinea, Vanuatu, the Bismarcks, and the Solomons. Specifically, Simmonds (1924) searched the northwestern coast of New Guinea, New Britain, Witu, New Ireland, Bouganville, Shortlands, Russell Group, New Georgia, Gela, Ysabel, Guadalcanal, Malaita, Manning Straits, Banks Group, Epi, Santos, Malakula, Pau Uma,
Aoba, Penticoste, Sandwich, and Tanna. This search failed to locate $L$. iridescens (Simmonds 1924). Concurrently, A. M. Lea of the Adelaide Museum (Australia) surveyed northern Queensland, Thursday Island group, and Magentic Island. Lea's efforts in 1924 also failed to locate L. iridescens (Despeissis 1925). Consequently, L. iridescens is known only from Fiji.

Lea then focused efforts in the Malay archipelago where he was assisted by $\mathrm{G}$. H. Corbett, B. A. R. Gater, and S. Leefmans in the search for another zygaenid, Artona catoxantha (Hampson), that exhibited periodic outbreaks resulting in defoliated palms reminiscent of damage caused by L. iridescens. Artona catoxantha was known to have a suite of natural enemies that effectively regulated its population growth. It was speculated that some of these natural enemies, should they be located, might attack L iridescens, because larvae of these two moths exhibited similar host plant associations, biology, ecology, and feeding behavior. Attempts by Lea and others to successfully ship live $A$. catoxantha parasitoids from the Federated Malay States to Fiji before 1925 failed. In 1925, H. W. Simmonds was stationed in Kuala Lumpur to await outbreaks of $A$. catoxantha and if possible to serendipitously coordinate shipments of parasitoids collected from unpredictable outbreaks located somewhere in the Federated Malay States with infrequent (approximately one to two per year) seagoing freighters leaving that area en route to Fiji. Airplanes were unavailable, and the cost of chartering a naval or merchant vessel for the 4,000-mile [6,437 $\mathrm{km}$ ] journey was prohibitive (Tothill et al. 1930). T. H. C. Taylor was dispatched by Tothill in 1925 to reexplore areas of New Guinea and then to travel on to Cochin China (i.e., South Vietnam). During this sojourn, Taylor stopped to visit Simmonds, and this trip coincided with an A. catoxantha outbreak at Batu Gajah, $175 \mathrm{~km}$ north of Kuala Lumpur.

\section{Importation and Release of Bessa remota in Fiji}

Parasitized and unparasitized larvae $(20,000$ in total) of $A$. catoxantha were collected, 
caged on 85 potted palms, and transported 300 miles [483 km] by train to Singapore where the cargo was loaded on the Clan Mackay for Surabaya, Java, on 10 July 1925. The cargo was transferred to the Clan Matheson on 12 July 1925 , and this ship arrived in Suva, Fiji, on 3 August 1925 with 315 live adult $B$. remota, 25 days after leaving Batu Gajah (Tothill et al. 1930). The suitability of L. iridescens as a host was unknown until the parasitoids arrived in Fiji and were presented with $L$. iridescens larvae in quarantine. In quarantine, adult flies immediately parasitized L. iridescens, and fly larvae developed successfully on L. iridescens. Hyperparasitoids were removed from the resulting B. remota colony that was being maintained on L. iridescens larvae. By January 1926, 32,621 flies had been successfully reared on L. iridescens and liberated. Within 6 months of release of this fly from quarantine in August-September 1925, L. iridescens populations had been reduced to almost nondetectable levels on Viti Levu, although persistent outbreaks continued on two small offshore islands (Nukulau and Makuluva) in the Rewa River delta in the southeastern corner of Viti Levu (Tothill et al. 1930). The biological control of L. iridescens by $B$. remota is cited as a premier example of classical biological control (Caltagirone 1981).

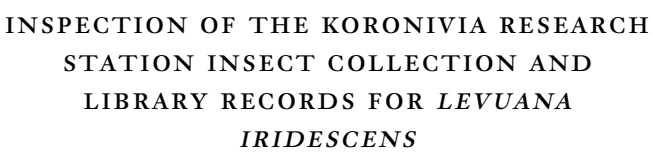

Speculation that L. iridescens was extinct by 1929 or may have persisted until the 1950 s and that the endemic $H$. dolens is extinct in Fiji (Robinson 1975, Howarth 1991, 2001, New 2005) was investigated by searching library-accessible literature records and Fijian insect collections.

\section{Koronivia Insect Collection}

In October 2002 and 2004, I examined the insect collection at the Koronivia Research Station near Suva on Viti Levu, Fiji, for $L$. iridescens and $H$. dolens. The Koronivia collec- tion has 14 specimens of adult L. iridescens: eight specimens have collection data, the remaining six are unlabeled. There are two $L$. iridescens cocoon samples on vulu: one is a single cocoon and the other is a mass of approximately 20 cocoons. One sample of larval $L$. iridescens trenching on the underside of a coconut leaf approximately 5 by $1.3 \mathrm{~cm}$ in size with around eight trenches has been preserved. The trenched leaf was collected in Serea, Viti Levu, 13 April 1939; the collector is not named. The most recently deposited specimens of adult $L$. iridescens were collected in December 1953 at Taulevu (due west of Vunindawa) on Viti Levu. Larvae were also collected from this L. iridescens outbreak in Taulevu that affected 100 coconut palms. The larvae were not located in the Koronivia collection. The most recently deposited specimens of $H$. dolens are two adults collected from Taulevu in 1963. Detailed collection data for $L$. iridescens and $H$. dolens are given in Table 1. In October 2004, a large number of unlabeled Schmidt Boxes and Cornell Drawers were inspected in the Koronivia Collection for "undiscovered" L. iridescens and $B$. remota specimens. The search yielded six additional L. iridescens and one cocoon sample. All of this "new" material was unlabeled so collection date and locality are unknown. Two of the best unlabeled adult L. iridescens specimens were sent to the Entomology Museum at the University of California, Riverside, for long-term curation. The overall condition of the specimens in the Koronivia Collection is extremely poor, and further deterioration will occur without immediate efforts aimed at preservation.

\section{Library Surveys}

Published outbreak records for L. iridescens after 1925 housed in library collections were searched for using Review of Applied Entomology: Agriculture. Accessible citations that were located were used to construct a map documenting the location and year of the published outbreak (Figure 2). The last published journal record was 1942 (17 yr after release of $B$. remota), and the final mention in the literature of $L$. iridescens being observed 
TABLE 1

Collection Records for Levuana iridescens and Heteropan dolens in the Insect Collection at the Koronivia Research Station, Viti Levu, Fiji

\begin{tabular}{|c|c|c|c|c|c|}
\hline $\begin{array}{l}\text { Specimen } \\
\text { No. }\end{array}$ & $\begin{array}{c}\text { Koronivia } \\
\text { Register No. }{ }^{a}\end{array}$ & $\begin{array}{l}\text { Collection } \\
\text { Locality }\end{array}$ & $\begin{array}{l}\text { Date of } \\
\text { Collection }\end{array}$ & $\begin{array}{l}\text { Name of } \\
\text { Collector }\end{array}$ & Comments in Register or on Labels \\
\hline $1^{*}$ & L.2276 & Taulevu & $?-12-1953$ & B. A. O'Connor & $\begin{array}{l}\text { Outbreak on } 100 \text { palms, larvae } \\
\text { collected }\end{array}$ \\
\hline $2^{*}$ & L.2276 & $"$ & $"$ & $"$ & $"$ \\
\hline $3^{*}$ & L. 816 & Vunindawa & $8-23-1941$ & $?$ & $\begin{array}{l}\text { Levuana and coconut flat moth } \\
(29-8-1941) \text { present in Vunindawa }\end{array}$ \\
\hline $4^{*}$ & L.29 & Serea & ?-?-1930 & T. H. C. Taylor & No entry in register \\
\hline $\begin{array}{l}5^{*} \\
6^{*}\end{array}$ & $"$ & " & " & $"$ & " \\
\hline $7^{*}$ & $"$ & $"$ & $"$ & $"$ & $"$ \\
\hline $8^{*}$ & L.816 & Vunindawa & $8-23-1941$ & $?$ & $\begin{array}{l}\text { Levuana and coconut flat moth } \\
(29-8-1941) \text { present in Vunindawa }\end{array}$ \\
\hline $9^{* *}$ & 755 & Vunindawa & $30-10-1932$ & H. Phillips & $\begin{array}{l}\text { No entry in register. Determined by } \\
\text { T. H. C. Taylor in } 1945\end{array}$ \\
\hline $10^{* *}$ & L. 2421 & Tailevu & $6-3-1963$ & J. Uluinaceva & $\begin{array}{l}\text { Collected from foliage. Determined by } \\
\text { W. G. Trenewan in } 1963\end{array}$ \\
\hline $11^{* *}$ & L.37 & Takeninoffia & $5-26-1926$ & R. W. Paine & No entry in register \\
\hline $12^{* *}$ & L. 38 & Waidau & $25-11-1927$ & H. W. Simmonds & No entry in register \\
\hline
\end{tabular}

${ }^{a}$ Refers to a journal entry with that particular log number that contains collection information cross-referenced to the number on the specimen label.

* Adult specimens of Levuana iridescens.

** Adult specimens of Heteropan dolens.

on Viti Levu was 1956 (31 yr after release) (Paine 1994).

\section{EXPLORATION OF VITI LEVU TO LOCATE LEVUANA IRIDESCENS}

D. P. A. Sands (CSIRO, Indooroopilly, Australia) and I attempted to locate $L$. iridescens on Viti Levu over the period 29 October-6 November 2002 in southeastern Viti Levu around Vunindawa, Colo-i-Suva, and Laucala Point. The search for larvae and adult moths followed two concurrent avenues: (1) visual inspection of palm fronds for larvae and coconut flowers for adult moths and (2) broadcast distribution of "wanted posters" with colored images of L. iridescens adults, larvae, and trenched leaves to village residents. The poster images were taken from the Tothill et al. (1930) treatise, and a US\$100 bounty was offered for the successful capture of any life stage of L. iridescens. The poster campaign was unsuccessful; no Lepidoptera were turned in for identification.

Tothill et al. (1930) stated clearly that visi- tors intending to witness $L$. iridescens damage to coconuts after release of $B$. remota should visit two islands in the Rewa River delta, $\mathrm{Nu}-$ kulau and Makuluva. Bessa remota had failed to provide consistent control of L. iridescens on these small isolated islands, and it was assumed that a lack of secondary hosts for $B$. remota to sustain itself during periods of low $L$. iridescens density was the major cause for this lack of persistent suppression (Tothill et al. 1930).

Attempts by D. P. A. Sands and me to gain access to Nukulau and Makuluva by motorboat were thwarted due to interception on the beach of Nukulau by the Fijian military, and access was denied. Both islands have been converted to prison camps to house militants responsible for the attempted 19 May 2000 coup d'etat lead by Fijian nationalist George Speight, and public access is prohibited. Further, the floral diversity of these two islands appears to have increased since Tothill et al.'s (1930) time. From the sea, visual observation suggested that the remnants of old coconut plantations were suffering from lack 
of human management because thick understories were evident. These prevailing conditions would most likely create habitat that would favor increased lepidopteran biodiversity, which may be conducive to sustaining $B$. remota populations leading to permanent suppression of $L$. iridescens on small offshore islands.

During an outbreak, L. iridescens exhibits a clear attack sequence. It preferentially attacks the tallest coconut palms in a highly localized area. Once these palms are defoliated, surrounding palms are then attacked, and the lowest-growing palms are infested last (Knowles 1919). Based on this description of the outbreak ecology of L. iridescens, and the fact that severe and prolonged outbreaks no longer occur, it is most likely that this insect inhabits its preferred feeding sites: the tallest palm trees in areas that support small populations. This preference for tall palm trees by L. iridescens may be one reason why visual searches for larvae on small immature coconut palms in southeastern Viti Levu were unsuccessful in 2002.

Consequently, if the tallest coconut palms are preferred for inhabitation by L. iridescens, then deployment of aerial malaise traps in coconut palm canopies may increase the probability of capturing adult moths. Aerial malaise traps (Figure 1D) were deployed at Serea, Taulevu, Vunindawa, and Toga Island near Nausori on the Rewa River delta over the period 5-31 October 2004. Traps were suspended on ropes $20-30 \mathrm{~m}$ above the ground between adjacent coconut palms and immediately under the palm crown. Traps were lowered on a rope pulley system, and collection bottles with $95 \%$ ethanol were checked every 3-4 days for L. iridescens, H. dolens, and B. remota over a 4-week period. None of the three target species was collected. This may be attributable to the short time frame during which surveys were conducted, a wellrecognized problem when sampling for rare species (Gaston 1994).

Visual searches of palm fronds for L. iridescens larvae were greatly hindered by feeding damage caused by larvae of another frond-trenching lepidopteran, the coconut flat moth, Agonoxena argaula Meyrick (Ago- noxenidae). This pest causes damage to the underside of palm fronds identical to that caused by L. iridescens. In direct contrast to L. iridescens, $A$. argaula larvae spin silk roofs over the open tops of trenches they inhabit. Abandoned trenches lack silk coverings and are impossible to distinguish from those made by $L$. iridescens larvae. In addition, $A$. argaula larvae drop to the ground to pupate, and they do not utilize vulu as a pupation site. Agonoxena argaula was present in Fiji during the "Levuana Campaign" but was apparently insignificant (Simmonds 1921b, Tothill et al. 1930). Population densities of $A$. argaula may have increased substantially following the successful biological control of $L$. iridescens because competition for the underside of palm fronds diminished.

\section{FUTURE RESEARCH AND ITS IMPORTANCE}

The creditability of the assertion that biological control of L. iridescens with B. remota in Fiji is one of the "best documented cases of extinction" (Howarth 1991:488, 2001:76) has been strongly challenged by biological control specialists (Sands 1997), invasion biologists (Kuris 2003), and zygaenid systematists (Tarmann 2004). Data supporting claims that natural enemies have driven $L$. iridescens to extinction are weak, because no comprehensive and prolonged campaigns to search for this zygaenid have been undertaken to verify its continued presence in Fiji. The published assumption of extinction of $L$. iridescens and $H$. dolens by $B$. remota has largely been accepted as fact (New 2005) despite a lack of confirmatory evidence (Lynch et al. 2001), museum records to the contrary (Table 1), and scattered published reports of persistent L. iridescens outbreaks up to 1956 (Figure 2). After 1956, research by entomologists employed by the Imperial Bureau of Entomology (also known as the Imperial Commonwealth International Institute of Entomology) to service tropical countries in the British Colonial Territories in the South Pacific began to wane, and research on Fijian coconut problems diminished. By 1966, the postwar Pacific island projects were ended, research teams returned to the United King- 
dom (Paine 1994), and Fiji gained full independence from Great Britain in 1970. The removal of entomologists who had worked on $L$. iridescens, reduction of the numbers of scientists and technicians working on coconuts (a crop of declining economic value), and a lack of regular published reports on pest surveys and outbreaks in Fiji may account in part for the cessation of reports of L. iridescens outbreaks and the lack of observations of $B$. remota, which has not been seen since the last observation of $L$. iridescens in 1956 (Paine 1994).

A survey of Review of Applied Entomology: Agriculture, Review of Agricultural Entomology (1913 to 1999 inclusive), and Commonwealth Agricultural Bureau Abstracts (2000 to 2004 inclusive) (all of these abstracting services have been run by the Commonwealth Agricultural Bureau or its predecessors) for publications and reports on pests of diseases of agricultural importance in Fiji indicates that during the period 1913-1965 an average of $10.85 \pm 1.14$ (SE) articles was published annually. This number is significantly higher $(t=6.79, \mathrm{df}=65$, $P<0.005)$ than the number of publications during the period 1967-2004, which averaged $2.63 \pm 0.41$ articles per year. These publication data tentatively support the suggestion that fewer scientists working on agricultural pest problems of importance in Fiji, especially coconuts, could in part, account for a lack of recent $L$. iridescens observations.

The endemicity of L. iridescens to Fiji is unresolved but has been questioned by Sands (1997) and Kuris (2003). If L. iridescens is native to Fiji, why did persistent outbreaks begin on Viti Levu around 1877? It is possible that new varieties of coconuts that were being grown in large plantations and the associated habitat modification allowed L. iridescens to completely escape any regulatory effect of its suite of endemic natural enemies. Further, this creation of natural enemy-free space via agricultural practices inexplicably extended to encompass a number of native Fijian palm species and other unrelated crop plants (e.g., bananas and breadfruit). This natural enemyfree space was initially restricted exclusively to Viti Levu before undetermined factors facilitated its extension onto nearby islands in 1916. This scenario, although interesting, seems implausible and makes it more likely that L. iridescens is exotic to Fiji, because it exhibited persistent population outbreaks and continued to spread into nearby and previously uninfested islands. Today, these phenomena are recognized as being representative scenarios typical of invasive species infiltrating new areas.

The claim that $H$. dolens is extinct in Fiji and that $B$. remota is responsible (Robinson 1975, Howarth 2001, New 2005) is worrisome. There are no published field or laboratory data indicating that $H$. dolens is attacked by $B$. remota, that $H$. dolens larvae are suitable hosts for B. remota on which to complete development, or that this fly forages in habitat or on host plants used by this zygaenid. Further, H. dolens is known to exist on other $\mathrm{Pa}-$ cific islands (e.g., Aneityum Island, Vanuatu [Robinson 1975]).

Zygaenids that are well regulated by natural enemies are known to exhibit long lag periods between outbreaks, and this is a clearly known facet of their ecology. For example, Artona chorista Jordan was presumed to have gone extinct until an outbreak $100 \mathrm{yr}$ after its initial description occurred in cardamom plantations in Sikkim, India (Tarmann 2004). Rarity of a given species is not a reliable predictor that extinction is inevitable or has occurred; and rarity may not have an important effect on the ecological viability of a species, especially if suitable habitat is available (Gaston 1994). If L. iridescens still exists in Fiji and is rare, some density-dependent population models indicate that rarity may be beneficial because attacks by upper-trophic-level organisms such as $B$. remota can be substantially reduced due to host scarcity and subsequent difficulty of detection (Kunin 1997). Conversely, stochastic environmental effects (e.g., cyclones) could threaten extinction of lowdensity L. iridescens populations in Fiji, but long-term monitoring of a single zygaenid population that dropped to as few as 20 adults suggests high resiliency to such events is possible if suitable habitat exists (Young and Barbour 2004).

It is very difficult to prove that the rela- 
tively recent absence of a species is due to its extinction. A robust approach to validate extinction would be to compile available data that a species is absent and then assess whether the combined weight of that evidence is sufficient to assume that extinction has occurred. This type of analysis is advocated by the Committee on Recently Extinct Organisms (2005, Holloway 2005), and editors of peer-reviewed articles should insist that these standards be reached before publishing statements that species extinctions have occurred. To substantiate or refute the extinction of $L$. iridescens by B. remota within the framework suggested by the Committee on Recently Extinct Organisms, a comprehensive multiyear search for L. iridescens in Fiji should be conducted. The best time to do this may be between August and December (historically, this time of year was most severe for L. iridescens), and efforts should be concentrated in the southeastern corner of Viti
Levu in the area circumscribed by Serea, Taulevu, Vunindawa, Colo-i-Suva, and Laucala Point (see Figure 2). The tallest coconut palms in these areas should form the foci of searches along with flowering plants with known attraction for adult $L$. iridescens seeking sugar sources.

Indirect evidence for the existence of $L$. iridescens could come from the discovery of pupal cases on vulu whose silk chemistry properties are identical to those of cocoons in the Koronivia Collection. Two subsamples of $L$. iridescens cocoons from the Koronivia Collection have been deposited in the Entomology Museum at the University of California, Riverside. Very small pieces from both cocoon samples were removed from masses and subjected to analyses to determine the "protein fingerprint" of the silk (see Garb and Hayashi 2005 for details on silk preparation and analysis). The results of the analyses (Table 2) indicated very little difference in

TABLE 2

Amino Acid Profile and Percentage Composition of Two Subsamples Taken from Each of Two Levuana iridescens Cocoon Clusters That Are Curated at the Entomology Museum, University of California, Riverside; Orange Tortrix, Argyrotaenia citrana, and Codling Moth, Cydia pomonella, Cocoon Amino Acid Profiles Are Provided for Comparison with L. iridescens Cocoons

\begin{tabular}{|c|c|c|c|c|c|c|}
\hline \multirow[b]{2}{*}{ Amino Acid } & \multicolumn{2}{|c|}{ Levuana Cocoon Sample 1} & \multicolumn{2}{|c|}{ Levuana Cocoon Sample 2} & \multirow{2}{*}{$\frac{\begin{array}{c}\text { Orange } \\
\text { Tortrix }\end{array}}{\%} \frac{\%}{\text { Composition }}$} & \multirow{2}{*}{$\frac{\begin{array}{c}\text { Codling } \\
\text { Moth }\end{array}}{\begin{array}{c}\% \\
\text { Composition }\end{array}}$} \\
\hline & $\begin{array}{l}\text { \% Composition } \\
\text { Subsample } 1\end{array}$ & $\begin{array}{c}\text { \% Composition } \\
\text { Subsample } 2\end{array}$ & $\begin{array}{l}\text { \% Composition } \\
\text { Subsample } 1\end{array}$ & $\begin{array}{c}\text { \% Composition } \\
\text { Subsample } 2\end{array}$ & & \\
\hline $\begin{array}{l}\text { Aspartic acid } \\
\text { and asparagine }\end{array}$ & 7.84 & 7.80 & 7.82 & 8.16 & 6 & 8 \\
\hline Threonine & 2.35 & 2.43 & 2.11 & 2.06 & & \\
\hline Serine & 25.81 & 25.22 & 24.50 & 25.22 & 8 & 9 \\
\hline $\begin{array}{l}\text { Glutamic acid } \\
\text { and glutamine }\end{array}$ & 4.05 & 4.14 & 3.65 & 3.50 & & \\
\hline Glycine & 27.83 & 27.87 & 29.24 & 29.20 & 25 & 25 \\
\hline Alanine & 19.85 & 19.80 & 20.83 & 20.63 & 8 & 17 \\
\hline Cysteine & 0 & 0 & 0 & 0 & & \\
\hline Valine & 1.83 & 1.90 & 1.60 & 1.52 & & \\
\hline Methionine & 0 & 0 & 0 & 0 & & \\
\hline Isoleucine & 1.62 & 1.73 & 1.69 & 1.51 & & \\
\hline Leucine & 3.53 & 3.64 & 3.45 & 3.24 & & \\
\hline Tyrosine & 2.72 & 2.63 & 2.96 & 2.91 & & \\
\hline Phenylalanine & 0.52 & 0.59 & 0.36 & 0.33 & & \\
\hline Lysine & 0 & 0 & 0 & 0 & & \\
\hline Arginine & 0.55 & 0.62 & 0.52 & 0.48 & & \\
\hline Proline & 1.53 & 1.62 & 1.25 & 1.24 & 18 & 17 \\
\hline
\end{tabular}


the amino acid profiles for both samples, suggesting that they are most likely from the same species. These profiles could be used to compare "fingerprints" from silk cocoons collected from vulu in Fiji to determine if they belong to L. iridescens. In some instances, silk amino acid profiles can be very specific to particular species (C. Hayashi, 2005, pers. comm.), and this forensic analysis could provide strong indirect evidence for the continued existence of L. iridescens in Fiji.

Direct evidence of the presence of $L$. iridescens would be the capture of adult moths or larvae. Aerial malaise traps should be hung between the tallest palms at canopy level in search areas to intercept adult moths flying to feed on coconut flowers or seeking oviposition sites or mates. Fogging of palm canopies with insecticides to knock down foliage feeders may result in the collection of adult or larval L. iridescens, but persistent maritime breezes will make this strategy very difficult (T. Irwin, 2004, pers. comm.). Surveys may best be conducted after cyclones have hit the Islands because of the disruptive effect major storms have on biological control agents, thereby allowing pest species to temporarily escape natural enemy regulation (Paine 1931, 1994).

Tothill et al. (1930) speculated that pheromones played a major role in mate location by male $L$. iridescens. Isolation and identification of a sex pheromone would enable the development of pheromone traps that could be deployed in island groups to the west of Fiji, the presumed historical home range of L. iridescens. Use of pheromone traps would allow the efficient sampling of low-density $L$. iridescens populations and would be an important tool in delineating the geographic range of this moth outside Viti Levu. Pheromone traps are used routinely for the monitoring of western grapeleaf skeletonizer, Harrisina metallica Stretch (= brillans Barnes \& McDunnough) (tribe Procridini), a pestiferous zygaenid of grapes in the United States (Soderstrom et al. 1985). Blends of pheromone constituents with known attractiveness to $H$. metallica could be deployed in Fiji in anticipation of eliciting partial responses (cross attraction) from male $L$. iridescens. However, $L$. iridescens (tribe Artonini) may not respond to procridin pheromone blends (Gerhard Tarmann, 2004, pers. comm.).

Finally, the nontarget impact and spread of $B$. remota in the Fijian Islands need research attention. The best approach to address these two issues would be through the use of food web analyses (Memmott 2000) in a manner similar to studies conducted in Hawai' $i$ to determine the magnitude of infiltration and impact on native species by the unintentional spread of exotic natural enemies into natural systems (Henneman and Memmott 2001). In this instance, food webs could be constructed for key lepidopteran species on Viti Levu and compared with food webs for the same species in similar habitats on Vanua Levu or other suitable islands where B. remota is not known to have established.

\section{ACKNOWLEDGMENTS}

I thank Roy Van Driesche, Don Sands, and Gerhard Tarmann for useful comments on an early draft of the manuscript. Cheryl Hayashi kindly performed the protein analyses on the L. iridescens cocoons and provided data from her "silk chemistry" database on other Lepidoptera for comparison with L. iridescens data. Ruth Vega spent many hours in the library tracking down obscure references for this article. Moti Lal, Sarlesh Kumar, Mereia Fong, and Koronivia field technicians provided access to field vehicles and assisted with locating suitable field sites for surveying. Christina Stosic diligently provided field assistance in Fiji and patiently sorted malaise trap samples at the Koronivia Research Station.

\section{Literature Cited}

Barnes, A. C. 1931. Annual report for the year 1930. Legislative Council, Fiji. Council Paper No. 56, Department of Agriculture, pp. 1-12.

1932. Annual report for the year 1931. Legislative Council, Fiji. Council Paper No. 20, Department of Agriculture, pp. 1-13. 
Bethune-Baker, G. T. 1906. New African Lepidoptera. Ann. Mag. Nat. Hist. 18:343-344.

Caltagirone, L. E. 1981. Landmark examples in classical biological control. Annu. Rev. Entomol. 26:213-232.

Committee on Recently Extinct Organisms. 2005. http://creo.amnh.org/ (accessed 30 July 2005).

Despeissis, A. 1925. Levuana moth of the coconut. Legislative Council, Fiji. Council Paper No. 44, Department of Agriculture, pp. 2-3.

Froggatt, W. W. 1914. Pests and diseases of coconut palm. N. S. W. Dep. Agric. Sci. Bull. 2:3-63.

Garb, J., and C. Hayashi. 2005. Modular evolution of egg case silk genes across orbweaving spider superfamilies. Proc. Natl. Acad. Sci. U.S.A. 102:11379-11384.

Gaston, K. J. 1994. Rarity. Chapman and Hall, London.

Henneman, M. L., and J. Memmott. 2001. Infiltration of a Hawaiian community by introduced biological control agents. Science (Washington, D.C.) 293:1314-1317.

Holloway, M. 2005. When extinct isn'tquestioning the term after a bird's return. Sci. Am. 293 (2): 22-23.

Howarth, F. G. 1991. Environmental impacts of classical biological control. Annu. Rev. Entomol. 36:485-509.

. 2001. Environmental issues concerning the importation of non-indigenous biological control agents. Pages 70-99 in J. A. Lockwood, F. G. Howarth, and M. F. Purcell, eds. Balancing nature: Assessing the impact of importing non-native biological control agents (an international perspective). Thomas Say Publications in Entomology: Proc. Entomol. Soc. Am., Lanham, Maryland.

Jepson, F. P. 1915. Report of the entomologist. Fiji Dep. Agric. Annu. Rep., 1914, Suva, pp. 17-27.

Knowles, C. H. 1909. Insects, \&c, injurious to cultivated crops. Fiji Dep. Agric. Annu. Rep. 27:35-39.

. 1919. The purple leaf moth of coconuts in Fiji. Reprinted 1924, Agric. Circ. Dep. Agric. Fiji 5 (1): 1-14.
Kunin, W. E. 1997. Population biology and rarity: On the complexity of density dependence in insect-plant interactions. Pages 150-173 in W. E. Kunin and K. J. Gaston, eds. The biology of rarity-causes and consequences of rare-common differences. Chapman and Hall, London.

Kuris, A. M. 2003. Did biological control cause extinction of the coconut moth, Levuana iridescens, in Fiji? Biol. Invas. 5:133-141.

Lever, R. J. A. W. 1938. Division of Entomology-Annual Report for 1937. Fiji Dep. Agric. 1:25-27.

- 1942. Division of EntomologyAnnual Report for 1941. Agric. J. Fiji Dep. Agric. 13:23-24.

Lynch, L. D., H. M. T. Hokkanen, D. Babendreier, F. Bigler, G. Burgio, Z. Gao, S. Kuske, A. Loomans, I. MenzlerHokkanen, M. B. Thomas, G. Tommasini, J. K. Waage, J. C. van Lenteren, and Q. Q. Zeng. 2001. Insect biological control and non-target effects: A European perspective. Pages 99-125 in E. Wajnberg, J. K. Scott, and P. C. Quimby, eds. Evaluating indirect ecological effects of biological control. CABI Publishing, Wallingford, United Kingdom.

Memmott, J. 2000. Food webs as a tool for studying nontarget effects in biological control. Pages 147-163 in P. Follet and J. J. Duan, eds. Nontarget effects of biological control. Kluwer Academic Publishers, Dordrecht, The Netherlands.

New, T. R. 2005. Invertebrate conservation and agricultural ecosystems. Cambridge University Press, Cambridge, United Kingdom.

Paine, R. W. 1931. Coconut committeeentomological report. Annu. Bull. Div. Rep. Fiji Dep. Agric. 1 (1): 1-8.

. 1994. Recollections of a Pacific entomologist, 1925-1966. ACIAR, Canberra, Australia.

Robinson, G. S. 1975. Macrolepidoptera of Fiji and Rotuma: A taxonomic and biogeographic study. E. W. Classey, Faringdon, Great Britain.

Sands, D. P. A. 1997. The safety of biological control agents: Assessing their impact on 
beneficial and other non-target hosts. Mem. Mus. Vic. 65:611-616.

Simmonds, H. W. 1920. Report on mission to Tahiti to investigate the parasites of the coconut scale with a view to their introduction to Fiji. Mon. Agric. Circ. Fiji Dep. Agric. 1 (7): 133-138.

. 1921a. Notes on Levuana iridescens. Mon. Agric. Circ. Fiji Dep. Agric. 2 (4): 84-85.

1921b. Report on coconut districts of Vunilagi and Macuata. Mon. Agric. Circ. Fiji Dep. Agric. 2 (3): 40-43.

. 1922. Spread of Levuana iridescens. Agric. Circ. Dep. Agric. Fiji 3 (4): 52-53.

- 1924. Mission to New Guinea, Bismarcks, Solomons, and New Hebrides. Legislative Council, Fiji. Council Paper No. 2, Department of Agriculture, $11 \mathrm{pp}$.

. 1925. Report by the acting government entomologist. Fiji Dep. Agric. Annu. Rep., Suva, 1924, pp. 7-9.

- 1930a. Report by H. W. Simmonds, Government Entomologist. Legislative Council, Fiji. Council Paper No. 42, Department of Agriculture, pp. 9-10.

- 1930b. Problems in biological control: The gap in the sequence of generations in Artona catoxantha, the coconut leaf moth of Malaya. Trop. Agric. 7:215-219.

—.1935a. Entomology Division annual report, 1935. Annu. Bull. Div. Rep. Fiji Dep. Agric. 8 (1): 19-22.

. 1935b. Entomological notes. Agric. J. (issued by the Department of Agriculture, Fiji) 8:32.

. 1936. Division of entomology annual report for 1936. Annu. Bull. Div. Rep. Fiji Dep. Agric. 1 (1): 27-29.
Soderstrom, E. L., D. G. Brandl, J. Myerson, R. G. Buttery, and B. E. Mackey. 1985. Sex pheromone for attracting western grapeleaf skeletonizer (Lepidoptera: Zygaenidae). J. Econ. Entomol. 78:799-801.

Tarmann, G. M. 2004. Zygaenid moths of Australia: A revision of the Australian $\mathrm{Zy}-$ gaenidae (Procridinae: Artonini). CSIRO Publishing, Collingwood, Australia.

Tothill, J. D. 1925a. Report by the Acting Entomologist for the year 1923. Levuana iridescens. Agric. Circ. Fiji Dep. Agric. 5 (2): $83-85$.

. 1925b. Levuana iridescens campaign. Legislative Council, Fiji. Council Paper No. 20, Department of Agriculture. . 1925c. An interim report on the Levuana campaign. Colonial Office Report. $3 \mathrm{pp}$.

3 1926. Work of the coconut committee. Legislative Council, Fiji. Council Paper No. 90, Department of Agriculture, p. 2.

1928. Annual report for the year 1927. Legislative Council, Fiji. Council Paper No. 75, Department of Agriculture, pp. 1-5.

Tothill, J. D., T. H. C. Taylor, and R. W. Paine. 1930. The coconut moth in Fiji: A history of its control by means of parasites. Imperial Bureau of Entomology, London.

Young, M. R., and D. A. Barbour. 2004. Conserving the New Forest burnet moth (Zygaena viciae [Denis and Schiffermueller]) in Scotland: Responses to grazing reduction and consequent vegetation changes. J. Insect Conserv. 8:137-148. 
